\title{
Edmodo Use to Develop Saudi EFL Students' Self-Directed Learning
}

\author{
Manal Mohamed Khodary ${ }^{1}$ \\ ${ }^{1}$ Faculty of Education, Suez Canal University, Ismailia, Egypt \\ Correspondence: Manal Mohamed Khodary, Faculty of Education, Suez Canal University, Ismailia, Egypt. \\ E-mail: manalkhodary@yahoo.com
}

Received: December 17, 2016 Accepted: January 19, 2017 Online Published: January 22, 2017

doi: 10.5539/elt.v10n2p123 URL: http://dx.doi.org/10.5539/elt.v10n2p123

\begin{abstract}
This study aimed at exploring the effect of Edmodo use on developing Saudi English as a Foreign Language (EFL) students' Self-Directed Learning (SDL). It employed a quasi-experimental design that included a one group design. The participants $(\mathrm{n}=45)$ were all fifth level students at Languages and Translation Department, Arar Faculty of Education and Arts, Northern Border University, Kingdom of Saudi Arabia. They were pre-tested before the treatment by using the pre Personal Responsibility Orientation to Self-Direction in Learning Scale (PRO-SDLS). They were post-tested after the treatment by using the post PRO-SDLS. The researcher taught the participants during the treatment which based on allowing them to use Edmodo in carrying out a project. The results revealed that a statistically significant difference in the participants' SDL between the pre PRO-SDLS and the post PRO-SDLS in favor of the post PRO-SDLS. Hence, it can be concluded that Edmodo helped the participants develop their SDL on the post PRO-SDLS. Some recommendations and suggestions for further research were included.
\end{abstract}

Keywords: edmodo, Saudi EFL students, self-directed learning

\section{Introduction}

\subsection{Background to the Study}

Self-Directed Learning (SDL) is a concept that attracts the attention of researchers as a subject of investigation in adult education field since the early 20th century (Gibbons, 2002). It is a procedure which gives students opportunities to be independent of their teachers in deciding the learning goals, selecting the learning task that they can accomplish and in completing it (Jossberger, et al., 2010). It is considered as lifelong learning (Candy, 1991; O'Shea, 2003). University students should not only master educational information, but they should also enjoy having SDL skills as well (Areglado, Bradley, \& Lane, 1996). Therefore, significant literature recommended instructional designs and faculty practices conducted to foster SDL among learners in order to enable them to pass their recent and future learning (Knowles, 1975; Brockett \& Hiemstra, 1991; Grow, 1991; Shaikh, 2013).

Edmodo is a closed social learning network which is considered unique compared to other Social Networking Sites (SNSs) such as Facebook and Twitter because it gives a safe, private setting to users. Each student has a private access code provided by the teacher and this private code enables her/him to join Edmodo. Hence, no strangers can join it. Besides, there is no personal information required from the students to join, so it is completely secure. This merit provides teachers and parents with peace of mind because they realize that students do not interact with strangers when they use Edmodo (Majid, 2011). Therefore, teachers and students can use it to safely connect online at any time to upload, exchange and share pictures, documents, blogs and web links and to collaborate and post ideas, notes and messages (Hankins, 2015).

The researcher worked as an associate professor at Languages and Translation Department at Arar Faculty of Education and Arts at Northern Border University (NBU) in Kingdom of Saudi Arabia (KSA). She noticed that most of fifth level students at this department had weaknesses in their SDL. Furthermore, the instructors at this department complained that these students suffered from weaknesses in SDL. The weaknesses were obvious in their inability to independently work out and manage their own learning. Moreover, they did not show responsibility to learn on their own. The researcher interviewed 21 fifth level students at this department to discuss the existence of these weaknesses among them. Most of the interviewed students stressed that although they used to carry out projects at their department, they had weaknesses in their SDL. 


\subsection{Problem Statement}

This study's problem was that there were weaknesses in SDL among fifth level students at Languages and Translation Department at Arar Faculty of Education and Arts. In order to solve this problem, the researcher carried out this study to explore the effect of Edmodo use on developing fifth level students' SDL.

\subsection{Review of Related Literature}

Some studies were conducted to describe influences of the Internet on enhancing students' SDL. Researchers revealed that the Internet has positive advantages for SDL. Bulik and Hanor (2000) stressed that the Internet can support SDL as it helps increase learners' control over knowledge and enables them to determine information relevant to them. Mathai (2002) pointed out that the Internet can foster SDL because it allows its users to easily reach large amounts of information and because it proved to be a communication means for its users. Ruelland (2003) indicated that the Internet can enhance SDL because it provides flexibility for users to learn quickly. Yen and Liu (2009) showed that the implementation of SDL in an online environment support learners' success. Lema and Agrusa (2009) stressed that learners who have high level experiences with online applications engage more in SDL activities. Conradie (2014) indicated that Web 2.0 is a key component in supporting learners' SDL.

Besides, recent studies revealed that SDL has positive outcomes for language learners. Reio and Leitsch (2003) concluded that students with a high level of SDL increase critical thinking among language learners. Gabrielle, Guglielmino and Guglielmino (2006) pointed out that students could have better academic performance when Self-Directed (SD) online media supplemented normal face-to-face lectures. King (2011) indicated that SDL can help students improve learning of English. Moreover, Yang (2015) concluded that utilizing a series of SDL based online workshops in an English for Specific Purposes (ESP) course had a positive effect on promoting learner's SDL.

\subsubsection{History of Edmodo}

Edmodo is a closed social network which Jeff O'Hara and Nic Borg founded and managed with the intent of creating an online learning environment for teachers and students to share ideas, assignments and events. It was first tested in 2008 and was made available for use thereafter. Edmodo has attracted the attention of teachers and students as a safe learning platform to communicate and collaborate with one another to share and exchange information by using any device with Internet access. It is considered as an effective tool in supporting a student's involvement in activities (Sanders, 2012). It has become famous for improving students' engagement in the course to enhance their educational outcomes and to help them achieve positive attitudes towards learning (Imlawi, 2013). It is a useful tool that can improve students' learning of English (Majid, 2011). Moreover, it has been used by researchers to develop students' learning of language skills. An example is Gardner's study (2013) which revealed that Edmodo can be used in writing composition classrooms to develop writing through peer review.

With the addition of languages for Edmodo, many teachers can use it internationally by adding any language of their own. Educational settings worldwide can also use Edmodo to develop students' learning. A huge increase can be noticed all over the world in the membership of Edmodo use among students and teachers. And, because it is used via the Internet, teachers and students from all parts of the world can access the specific pages of Edmodo for their classrooms. In fact, Edmodo has become more and more popular worldwide. Besides, since Edmodo is still a relatively new social learning network, its makers are continuously integrating teachers' feedback to make improvements to it (Kenney, 2010; Sanders, 2012).

Although Edmodo is used at many universities all around the world as an effective platform for fostering students-instructors communication and as a means for distance education and although it is gaining popularity as an effective and beneficial tool for pedagogic purposes to be used by university students to help them share experiences and collaborate on relevant topics, its use is still rare in KSA universities. The researcher did not find any studies that were conducted on the effects of using Edmodo on developing SDL among university students in KSA.

\subsubsection{Merits of Edmodo}

Merits of Edmodo are as follows:

- It is private and closed for only educational uses by its users (Duncan \& Chandler, 2011) and it does not contain any advertisements.

- It is free because its users do not need to pay any fees when they join and use it (Prasad \& Prasad, 2012).

- Transmission by using Edmodo is fast and it is friendly to the environment because it saves paper. 
- It is easy for students to use Edmodo as it does not need any technical competence on the part of its users (Holland \& Muilenburg, 2011).

- Edmodo and Facebook are similar in some features such as profile appearance and in enabling its users to provide comments and posts (Haefner \& Hanor, 2012). But, it differs from Facebook because it is a safe, closed network which gives teachers and parents piece of mind as no strangers can see students' posts or visit it without teacher's permission. Hence, students can use it to safely publish their work and ideas and no strangers can read what they published on it and they cannot communicate with them (Deshpande, 2016).

- It is easy for the students to register in Edmodo because they do not need personal E-mail accounts to join it and they do not have to include any personal information in profile to register in it. Their teacher is the only person who accepts on their registration in Edmodo (E. Prasad \& R. Prasad, 2012).

- It allows students to upload home assignments and view own grades posted by their teacher to it (Majid, 2011).

- It enables students to post private messages to their teacher and to one another.

- It allows students to answer polls and quizzes on it, and it enables them to communicate together and with their teacher directly to ask her/him a question or to tell that they will not be able to attend class.

- It is helpful for the students who are absent from class or who need extra help to follow the information posted by their teacher to it and for independent learning.

- It allows students to enhance their learning outside of the regular classroom because with it they have the capacity to work from their Internet-enabled devices at home and anywhere.

- It is user friendly because it is easy to learn and use quickly even for those students who have never used SNSs (Kongchan, 2012).

- It gives students' parents the opportunity to join it in order to follow their kids' grades, discussions and participation on it. Parents can also communicate with their kids' teacher on it.

- It enables teachers and students to upload, exchange and share videos, blogs, Internet links, documents, notes and Power Point Presentations (PPTs) to foster communication at any time and place (Hankins, 2015).

- It allows teachers and students to participate in online discussions through the message board (Kongchan, 2012).

- It includes a class calendar that keeps all home assignments and announcements of activities and events organized for teachers and students.

- It allows students and teachers to create connections with other students and teachers with similar interests from different schools, countries, or cultures to collaborate by adding their own ideas and to share events and knowledge (Sanders, 2012).

- It enables teachers to conduct online polls for their students about a certain topic.

- It helps teachers post home assignments and quizzes for their students to answer online (Turkmen, 2012).

- It permits teachers to post grades to students and to give them feedback and suggestions for improving performance. Teachers can also use it to give students positive encouragement privately and in public.

- It helps teachers develop their Personal Learning Network (Kongchan, 2012).

- There are text alerts available on it to remind students of assignments (Deshpande, 2016).

- It enables teachers to create small groups of students on it so as to differentiate instruction to them and to help them work on projects collaboratively (Curran-Sejkora, 2013).

- It provides technical support when teachers need it because Edmodo team always answers teachers' enquiries and quickly provides solutions for any problems they encounter.

\subsubsection{Historical Development of SDL}

SDL was systematically studied in the 20th century as a result of the development in the field of adult learning. It emerged as a consequence of researchers' tries to seek for a method that enabled them to distinguish the ways children and adults learnt (Merriam, 2001). SDL first appeared in works done at the United States in the early 20th century to help comprehend how adults learnt. Examples were works conducted by Tough $(1967 ; 1971)$ on SDL and important suggestions to promote SDL from organizations to group learning have then been arisen.

In fact, research of SDL has noticeably expanded in the field of adult instruction since Tough's work in 1971 
(Merriam, Caffarella, \& Baumgartner, 2007). At the beginning, researchers had focused on the instructional design for adult learners by identifying relevant resources, selecting instructional formats and evaluating learning outcomes. Then, from the 1980 's, researchers started to examine the learning processes, namely the learner characteristics, the learning context and the nature of learning itself (Grow, 1991; 1994). SDL is currently regarded as an essential skill in the 21 st century and a requirement for all students. It is also connected to lifelong learning, which has been recognized as a demand for modern society (Dynan, Cate, \& Rhee, 2008). Schools and colleges price the importance of SDL skills which are highly required to perform within the 21 st century (Murnane \& Levy, 1996). Therefore, SDL has received the attention of researchers as a topic of investigation.

\subsection{Hypothesis of the Study}

There would be a statistically significant difference $(\alpha<0.05)$ in fifth level Languages and Translation Department students' SDL between the pre PRO-SDLS and the post PRO-SDLS in favor of the post PRO-SDLS.

\subsection{Objectives of the Study}

The present study aimed at answering the following questions:

- How can Edmodo help in developing fifth level Languages and Translation Department students' SDL?

- Is there any statistically significant difference in fifth level Languages and Translation Department students' SDL between the pre PRO-SDLS and the post PRO-SDLS?

\subsection{Significance of the Study}

This study's findings are supposed to be significant to fifth level Languages and Translation Department students in KSA because they may provide them with information regarding how to make use of Edmodo in order to develop their SDL. They are also supposed to be significant to English as a Foreign Language (EFL) instructors at faculties of education and arts because they may reveal how Edmodo can be incorporated in teaching their courses so as to assist them to develop their students' SDL. Moreover, they may be significant to the parents of the students who use it because they could enable them to know that their kids can safely use Edmodo because it is a secure social learning network. They may also reveal to students' parents that they can use Edmodo to follow up their kids and communicate with their teachers to help them in their learning process.

\section{Method}

\subsection{Research Design}

It is a quasi-experimental design that employed a one group design. The participants were pre tested on SDL by using the pre PRO-SDLS before the treatment and then post tested by using the post PRO-SDLS after the treatment. The difference between the pre PRO-SDLS and the post PRO-SDLS was calculated.

\subsection{Variables}

The independent variable in this study is Edmodo use while the dependent variable is fifth level Languages and Translation Department students' SDL. The operational definitions of these two variables are mentioned below.

\subsubsection{Edmodo}

The researcher operationally defined Edmodo as a secure social learning platform which enables teachers and students to facilitate collaboration at any time and any place by using any mobile devices supplied with Internet access so as to accomplish pedagogical achievements.

\subsubsection{Self-Directed Learning}

The researcher operationally defined SDL as a procedure through which individuals demonstrate better self-efficacy and better motivation factors and show greater interest in identifying various resources for learning and in accomplishing the learning tasks independently and with others' help.

\subsection{Participants}

The participants $(n=45)$ were fifth level Languages and Translation Department female students at Arar Faculty of Education and Arts. They ranged from 21-22 years. They spent at least 13 years in learning EFL. All the participants had not any former practice with using Edmodo prior to the treatment. The researcher trained the participants throughout all of the project stages.

\subsection{Instrument}

\subsubsection{The PRO-SDLS (See the Appendix)}

The researcher used the Personal Responsibility Orientation to Self-Direction in Learning Scale (PRO-SDLS) 
(See the Appendix) as an instrument to assess the participants' SDL before and after the treatment. She adopted the PRO-SDLS from Stockdale (2003) who designed it as a result of her try to create a reliable and valid instrument to be used to assess SD among college students (Stockdale \& Brockett, 2011). The researcher selected this scale for the present study because it is applicable to measure SDL among students in higher education. Moreover, it is a recent instrument in the field of SDL measurement and because it has been lately used in several studies (Holt, 2011). The PRO-SDLS was found to enjoy a high degree of validity and reliability (Stockdale \& Brockett, 2011). Pearson product moment correlation coefficient was used and pointed out that PRO-SDLS' scores revealed an r-value of $<.70$ in relation to the Self Directed Learning Readiness Scale (SDLRS) (Stockdale, 2003). Fogerson (2005) confirmed the PRO-SDLS' reliability because it achieved a coefficient alpha of .91.

The PRO-SDLS is a five-point Likert scale which contains 25 test items that represent the values strongly disagree, disagree, sometimes, agree and strongly agree. It was based on the theoretical constructs of the Personal Responsibility Orientation (PRO) Model of Self-Direction in Learning designed by Brockett and Hiemstra (1991). It measures the two main components of SD in learning: the teaching-learning transaction component and a learner characteristic component (Stockdale, 2003). The researcher submitted the PRO-SDLS to a pilot sample of 25 fifth level Languages and Translation Department students at Arar Faculty of Education and Arts to find out whether this scale and its instructions are clear and comprehensible to them. The pilot sample stressed that the PRO-SDLS and its instructions are clear and comprehensible. The researcher submitted the PRO-SDLS to a jury of 7 judges, professors of Curriculum and Teaching English as a Foreign Language (TEFL) instruction at some faculties of education and arts in KSA to ensure its validity. The jury agreed upon the validity of the PRO-SDLS for assessing fifth level Languages and Translation Department students' SDL.

The researcher assessed the reliability co-efficient of the PRO-SDLS by using the test / retest method of calculating its reliability. This was done by administrating the PRO-SDLS twice with a 15 day time span on a random sample of 23 fifth level Languages and Translation Department students at a Faculty of Education and Arts in KSA and not included in the present study's participants. The statistical co-efficient of Pearson on the PRO-SDLS was found at 0.91 which is a high co-efficient reliability at 0.01 level. This showed that the PRO-SDLS has a high degree of reliability. Hence, the validity and reliability of the PRO-SDLS were confirmed and this revealed the applicability of this instrument for SDL's measurement in the present study.

\subsection{Procedures}

The present study was conducted at Languages and Translation Department, Arar Faculty of Education and Arts, NBU, KSA because the researcher worked as an associate professor at this faculty. The participants were fifth level Languages and Translation Department students at this faculty because the researcher taught Research Methods course to these students. NBU implemented Project-Based Learning (PBL) into Research Methods course as a preferred form of learning provided to fifth level Languages and Translation Department students at Arar Faculty of Education and Arts to fulfill the requirement of the National Commission for Academic Accreditation and Assessment (NCAAA) for faculties of education and arts in KSA. PBL is a process of developing learner's mind qualities to accomplishing integration of operational and instructional approaches to solve a problem or carry out a project. It requires students to collect resources, organize work and manage long-term activities. It also requires students to design, revise and share their ideas and experiences with authentic audience. SDL can be embedded in PBL.

In the present study, the treatment lasted for 12 weeks with 5 hours per week as required for training the participants on using Edmodo in conducting the project to develop SDL among them. The researcher assessed the participants' SDL before conducting the treatment by using the pre PRO-SDLS. She post-tested them by using the post PRO-SDLS by the end of the treatment. And then, the difference between the mean scores of the pre PRO-SDLS and the post PRO-SDLS was calculated to find whether there is any statistically significant difference in the participants' SDL between the pre PRO-SDLS and the post PRO-SDLS. The project's idea was based on developing the participants' ability to write an abstract for a research paper. The title of the project's topic was: Past-Forward to the Future. The project in the present study included the following stages: countdown to project launch, project launching, throughout the project and project evaluation.

\subsubsection{Countdown to Project Launch}

The researcher notified her department members about the project. They participated with her in selecting the idea of the project. She agreed with them that the project would be about writing an abstract which based on the research topic: Past-forward to the future. They participated with her in planning the project stages. She also discussed with them students' roles in the different stages of the project. Then, she created a class Edmodo for 
the Research Methods course and named it (AGA \& AGB Research Methods Edmodo). She made an account on Edmodo for each participant and provided each one with her own password and username on Edmodo to privately and safely use it. She trained the participants on how to log on to Edmodo by using own password and username and how to insert pictures into their profiles in order to distinguish their profiles from others. She rewarded them with badges when they completed their initial log on to Edmodo. She allowed them to choose pictures for their profiles of Edmodo pages to identify themselves when they interact with her. She also rewarded them with other badges when they inserted pictures on their profiles. Besides, she gave them the opportunity to individually vote for their opinions regarding the project idea by using the polling feature on Edmodo. All of the participants voted that they agreed on the project idea.

Then, the researcher requested the participants to assign themselves according to their interests into small groups of 5 students in each group because the participants in each small group should collaborate together to accomplish the project. The participants assigned themselves into 9 small groups on Edmodo and the researcher gave a different name for each small group on it. The participants in each small group took part with the researcher in selecting the resources which they might need to carry out the project. The researcher procured copies of attachments like checklists, rubrics and documents. She organized and posted them to Edmodo as they were needed for the participants to use. She also posted a copy of video of Kennedy's address to participants in an American university to Edmodo for the participants to watch it when she asked them to do. She trained the students on the use of the attachments which she had posted to Edmodo like abstract checklist, peer review checklist, collaboration rubric, discussion checklist, and presentation rubric. She also trained them on how to use Edmodo individually as well as collaboratively in their small groups and whole class to post attachments like videos, pictures, web links, how to write and post comments to Edmodo, and how to use the calendar and the library on it, and how to answer polls and quizzes on it. The participants were allowed to access the rubrics and checklists on Edmodo to assess their own and other small groups' abstracts throughout the project stages. They were also notified that they should use Edmodo to communicate, discuss and exchange opinions about the project topic with the researcher, small group and whole class. They were also told that they should use it to post individual and small groups abstracts to it, comment on abstracts and use the attachments posted to it. The researcher explained project stages to the participants. She informed them that she would check assignments with each individual and each small group on a regular basis to ensure they were moving toward applying the project objectives. She also told them that each student should take part in checking the project requirements for the whole class. She gave them the opportunity to take part in setting the timing of the project stages. They participated with her in assigning due dates for posting their assignments to Edmodo. They also participated with her in scheduling the project and then, she posted it into Edmodo calendar.

\subsubsection{Project Launching}

To generate the participants' interest to the project, the researcher introduced to them the video of Kennedy's address which she had posted to Edmodo. Each participant individually watched the video and then individually wrote an abstract on the topic of this video. Then, all of the participants created a whole class abstract of the speech with the help of the abstract checklist which the researcher had posted to Edmodo. This step served to model the format of the abstract because it is their first experience with writing abstracts. The researcher presented to the participants the following driving question: how is the past influencing your future? This question was intended to engage their attention and focus their efforts on the topic of the project. The participants held whole class meetings to brainstorm and discuss together and with the researcher their ideas about their response to the driving question.

The researcher taught the participants the objectives of this project in a mini-lesson. Then, she presented to them an introduction about the topic of the project to attract their attention to take part in the project. And, she told them that the project is about writing an abstract on the project topic: Past-forward to the future. She introduced the project idea to them by indicating that by using $17^{\text {th }}, 18^{\text {th }}, 19^{\text {th }}, 20^{\text {th }}$, and $21^{\text {st }}$ century United States (US) documents which were posted to Edmodo each participant should individually write and post to Edmodo an abstract on a US document keeping in mind the driving question when writing the abstract. Then, she explained to them that each small group had to collaborate together to use their individual abstracts and the comments which she posted to them on Edmodo about their individual abstracts in order to write and post one abstract for the group to Edmodo. She also told them that after this step, each small group had to create and present to other small groups and the researcher an oral Power Point Presentation (PPT) which would last for 20 minutes to share with them the information of their small group abstract on the project topic. 


\subsubsection{Throughout the Project}

Each participant previewed all the US documents which the researcher had posted to Edmodo. Then, each participant selected one document from each century to write her individual abstract on the project idea. The researcher scaffolded reading strategies to use to help the participants access the information in the US documents by asking the participants to choose to use SQ3R, or Strategy for Reading Nonfiction. Each participant conducted a close reading of the materials which she had selected. The researcher reviewed with the participants' criteria of using the abstract checklist to help them in writing their abstracts. Then, each participant wrote a draft of her abstract and posted it to Edmodo. After that, each participant used the peer review checklist to review her abstract with a partner for feedback and she individually modified her abstract and reposted it to Edmodo for researcher's feedback. The researcher commented on each abstract on Edmodo and held a meeting with each participant to discuss her abstract for modifications. Then, each participant worked with her small group to discuss their individual abstracts by using the discussion checklist posted to Edmodo to make one abstract for their small group and then, they posted it to Edmodo to get feedback from other small groups and the researcher. The researcher monitored each small group's discussions on their own abstract. She also checked each small group's abstract posted to Edmodo in order to know the information the participants were gleaning from the project. She commented on the abstracts to help them when they write their future abstracts and gave each small group the opportunity to make modifications for own abstract.

\subsubsection{Evaluating the Project}

Each small group discussed with researcher the outline for their own oral PPT. They participated with her in setting out a plan for small groups' oral PPTs. The researcher explained to them their responsibilities and she assigned different roles for the small groups during the oral PPTs. For example, while one group is presenting, three groups might be taking notes on the presentation, three groups might be evaluating the presentation by using the presentation rubric posted on Edmodo, and two groups might be generating questions to pose about the content of the presentation. The researcher revised with the participants the use of the presentation rubric which she had posted on Edmodo to evaluate each individual's part in the small group's oral PPT. Each small group decided the overriding theme of own abstract that they would use for their group presentation and keeping in mind the driving question. Then, they created and presented own group oral PPT in front of audience. Furthermore, they responded to questions from the audience about the topic of their presentation. By the end of each presentation, each small group provided a final answer to the driving question. The whole class reflected on their responses to the driving question through whole class discussion. Then, each participant in each small group self-evaluated own performance on Edmodo by writing a reflective piece describing what she had learned and what she had contributed to group performance. The researcher also reflected on the project and she used the results of these reflections to refine the project for future use. The whole class and the researcher celebrated the completion of the project by noting successes and posting them to Edmodo. Moreover, the researcher rewarded the participants with badges on Edmodo for the completion of the project.

\section{Result}

Paired-samples t-test was used in order to test the difference between the means of scores of the participants on the pre PRO-SDLS and post PRO-SDLS. The difference was statistically significant $(\mathrm{t}=24.48, \mathrm{p}<0.05)$. This result is presented in Table 1. The effect size for the difference was estimated by using Brown's (2008) formula. The effect size was 0.931 which is considered large.

Table 1. Paired-samples t-test of the difference between the means of the participants' scores on the pre PRO-SDLS and the post PRO-SDLS

\begin{tabular}{lllllll}
\hline & \multicolumn{2}{l}{ Paired Differences } & & $\mathrm{t}$ & $\mathrm{df}$ & Probability \\
Post PRO-SDLS & Mean & Std. Deviation & Std. Error Mean & & & \\
\cline { 2 - 7 } Pre PRO-SDLS & 57.77 & 6.42 & 2.36 & 24.48 & 44 & Significant \\
\hline
\end{tabular}

\section{Discussion}

In this study, it was hypothesized that there would be a statistically significant difference $(\alpha<0.05)$ in the participants' SDL between the pre PRO-SDLS and the post PRO-SDLS in favor of the post PRO-SDLS. The result revealed that a statistically significant difference was found in the participants' mean scores between the pre PRO-SDLS and the post PRO-SDLS in favor of the post PRO-SDLS. This significant result might be a 
consequence of using Edmodo by the participants in conducting the project. Edmodo enabled the participants to develop responsibility in self through individual activities and collaboration with small groups, whole class and the researcher. This result revealed that the participants became more self-disciplined, and more confident in completing the tasks on their own. They became SD learners enjoying the characteristics of SD learners as mentioned by Jossberger, et al. (2010) that a SD learner is the one who is able to organize, accomplish, and complete learning independently.

Edmodo is a secured and closed tool which can be used privately by each participant in carrying out the project requirements (Hankins, 2015). This characteristic helped the participants feel safe and hence they had great interest in the task because they realized that no strangers can see their own comments or comment on their own work. Another characteristic of Edmodo was the ease of use and transmission on the part of the participants because they can easily use it to access assignments at any time and any place on their mobile devices which are supplied with Internet access. Besides, Edmodo is user friendly to its users (Kongchan, 2012). Hence, each participant in the present study learned its use in conducting projects quickly. Moreover, Edmodo did not need any technical competence from the participants and the researcher to do the activities required from them on it. Therefore, Edmodo allowed each participant to independently choose and implement learning strategies, select learning resources, do assignments, complete the learning tasks and demonstrate oral presentations. It also gave each participant the facility to individually and collaboratively use it to post own ideas, assignments, forms, notes, abstracts and get feedback directly from the researcher and their peers. Furthermore, Edmodo enabled the participants to interact privately and in public together and with the researcher.

The calendar on Edmodo organized the announcement of assignments and activities (Deshpande, 2016). This made it easy for the researcher to post bell-ringers, organize time for tasks and assignments to help the participants actively and independently engage in the project stages. The text alerts on Edmodo reminded the participants of the activities. Moreover, the message board on Edmodo gave each participant the chance to participate in online discussion. Edmodo also enabled each participant to see own grades posted to it by the researcher. The library on Edmodo gave the participants the opportunity to individually and collaboratively select resources from it to get information and increase knowledge to help them in writing their abstracts. Edmodo also gave the researcher the facility to give positive encouragement to each participant privately and in public. The badges provided to the participants by the researcher encouraged them for more participation in all project stages. This encouragement which the participants received from the researcher on Edmodo helped them become more able to demonstrate a greater responsibility to individually and actively do the tasks.

The participants reflected throughout the project in their individual researcher-student meetings and wrote their reflections on Edmodo. The researcher also reflected on what is going well and why as well as what needs improvement and why throughout the project and she wrote her reflections on Edmodo. She also used the written abstracts on Edmodo, the explicit feedback provided during researcher student meetings in order to post descriptive feedback to Edmodo on how the participants can improve their performance before their oral PPTs to successfully complete the project. There was an increase in the participants' participation in Edmodo to publish ideas, respond to posts, answer polls, post assignments, and respond to comments. Each participant accessed the rubrics and checklists on Edmodo to assess the work of own, peers and small groups. Each participant also used Edmodo to individually write and post assignments on time taking the responsibility of her own learning.

The researcher gave each participant the opportunity to individually answer a poll on Edmodo to give opinions regarding own reactions towards the use of Edmodo in conducting the project. It was obvious that all of the participants took ownership for their work and were pleased that their final abstracts were presented to the audience during the evaluation stage of the project. They wrote comments to the vote of the poll revealing positive attitudes towards carrying out projects by using Edmodo. They pointed out that they enjoyed participating in conducting the project through using Edmodo. They added positive comments regarding their experience with using Edmodo in carrying out the project. They stressed that Edmodo fostered communication among them and the researcher at any time and place and this enhanced learning outside of the classroom. They appreciated Edmodo's use in the project because they regarded it as an effective tool for developing their SDL. They indicated that they would like to use Edmodo in the future with other courses.

\section{Conclusion}

It can be concluded from the present study that Edmodo use in carrying out the project helped the participants develop their SDL. Therefore, Edmodo proved to be an effective tool for students to be used individually and collaboratively in order to support their responsibility for learning and develop their SDL. 


\section{Recommendations and Suggestions}

Based on the present study's results, the researcher introduces the following recommendations:

- EFL university instructors should be trained on how to use Edmodo in developing SDL among students.

- Curriculum developers and textbook writers should include activities based on using Edmodo to develop SDL among students.

- Published handouts on how teachers can use Edmodo to develop SDL among students should be provided to instructors of EFL at the university level.

Furthermore, the researcher suggests carrying out studies undertaking:

- A replication of the present study with more number of students to generalize the results.

- Investigating students' attitudes towards using Edmodo in developing their SDL.

- Comparing the effect of other SNSs such as Facebook or Twitter versus Edmodo on developing SDL among university students.

- Examining the effect of using Edmodo in teaching other courses on developing SDL among students.

\section{Acknowledgments}

Many thanks should go to the participants for willingly taking part in the present study.

\section{References}

Areglado, R., Bradley, R., \& Lane, P. (1996). Learning for Life: Creating Classrooms for Self-Directed Learning. Thousand Oaks, CA: Corwin Press, Inc.

Brockett, R., \& Hiemstra, R. (1991). Self-direction in adult learning: Perspectives on theory, research, and practice. London and New York, NY: Routledge. Retrieved from http://www-distance.syr.edu/sdlindex.html

Brown, J. (2008). Effect size and eta squared. JALT Testing \& Evaluation SIG Newsletter, 12(2), 38-43.

Bulik, R., \& Hanor, J. (2000). Self-directed learning in a digital age: Where next to browse is informed by reflection. In H. B. Long \& Associates, Practice \& theory in self-directed learning (pp. 265-276). Schaumburg, IL: Motorola University Press.

Candy, P. (1991) Self-direction for lifelong learning: A Comprehensive Guide to Theory and Practice. San Francisco: Jossey-Bass.

Conradie, P. (2014). Supporting Self-Directed Learning by Connectivism and Personal Learning Environments. International Journal of Information and Education Technology, 4(3), 254-259. https://doi.org/10.7763/IJIET.2014.V4.408

Curran-Sejkora, E. (2013). Student Interactions in Edmodo versus facebook (Doctoral dissertation). http://hdl.handle.net/2286/R.I.20858

Deshpande, S. (2016). Arousal and Learning of Language through Edmodo. Journal of Technology for ELT. https://sites.google.com/site/journaloftechnologyforelt/archive/volume-6-number-1-january---march-2016/2 -arousal-and-learning-of-language-through-edmodo

Duncan, J., \& Chandler, P. (2011). A community of practice for early career Biology teachers: Social networking and digital technologies. Proceedings of the Contemporary Approaches to Research in Mathematics, Science, Health and Environmental Education, Deakin University, Melbourne Burwood Campus.

Dynan, L., Cate, T., \& Rhee, K. (2008). The impact of learning structure on students' readiness for self-directed learning. Journal of Education for Business, 84(2), 96-100. https://doi.org/10.3200/JOEB.84.2.96-100

Fogerson, D. (2005). Readiness factors contributing to participant satisfaction in online higher education courses. Unpublished doctoral dissertation, University of Tennessee, Knoxville, TN.

Gabrielle, D., Guglielmino, L., \& Guglielmino, P. (2006). Developing self-directed learning readiness of future leaders in a military college though instructional innovation. International. Journal of Self-Directed Learning, 3, 24-35.

Gardner, M. (2013). Social media and peer review: Edmodo in the composition classroom. Dissertations, Theses and Capstone Projects. Kennesaw State University. Retrieved from http://digitalcommons.kennesaw.edu/cgi/viewcontent.cgi?article=1561\&context=etd

Gibbons, M. (2002). The self - directed learning handbook: Challenging adolescent students to excel. San 
Francisco, CA: Jossey - Bass.

Grow, G. (1991). Teaching learners to be self - directed: A stage approach. Adult Education Quarterly, 41(3), 125-149. https://doi.org/10.1177/0001848191041003001

Grow, G. (1994). In defense of the staged self - directed learning model. Adult Education Quarterly, 44(2), 109-114. https://doi.org/10.1177/074171369404400206

Haefner, J., \& Hanor, J. (2012). iPads apps for utility and learning. Proceedings of the 28th Annual Conference on Distance Teaching and Learning, 1-5.

Hankins, N. (2015). The Effects of Edmodo on Student Achievement in Middle School. (Doctoral dissertation) Retrieved from ProQuest Dissertations and Theses database. (UMI Number 3715320).

Holland, C., \& Muilenburg, L. (2011). Supporting student collaboration: Edmodo in the classroom. Proceedings of Society for Information Technology and Teacher Education International Conference 2011, Chesapeake, VA, 3232-3236.

Holt, L. (2011). Self-direction and technology use among new workforce entrants. (Unpublished doctoral dissertation). University of Tennessee, Knoxville. http://trace.tennessee.edu/utk_graddiss/1191

Imlawi, J. (2013). Improving student engagement using course-based social networks. (Doctoral dissertation) Retrieved from ProQuest Dissertations and Theses database. (UMI Number 3562640).

Jossberger, H., Brand-Gruwel, S., Boshuizen, H., \& Wiel, M. (2010). The challenge of self-directed and self-regulated learning in vocational education: a theoretical analysis and synthesis of requirements. Journal of Vocational Education and Training, 62(4), 415-440. https://doi.org/10.1080/13636820.2010.523479

Kenney, E. (2010). History and definition of Edmodo. Retrieved from http://wiki.itap.purdue.edu/display/Edmodo+Research+Page

King, C. (2011). Fostering self-directed learning through guided tasks and learner reflection. Studies in Self-Access Learning Journal, 2(4), 257-267.

Knowles, M. (1975). Self-directed learning: A guide for learners and teachers. New York, NY: Association Press.

Lema, J., \& Agrusa, J. (2009). Relationship of WWW usage and employee learning in the casino industry. International Journal of Hospitality Management, 28(1), 18-25. https://doi.org/10.1016/j.ijhm.2008.03.010

Majid, N. (2011). The use of information technology in teaching English: An attempt to develop student-centered learning at Telkom Polytechnic. In Prosiding Konferensi Nasional ICT-M Polytechnic Telkom (KNIP). Retrieved from http://openjurnal.politekniktelkom.ac.id/

Mathai, R. (2002). The use of the Internet to foster self-directed learning in community and technical college math and natural science classes. In H. B. Long \& Associates (Eds.), Twenty-First Century advances in self-directed learning (pp. 127-153). Boynton Beach, FL: Motorola University.

Merriam, S. (2001). Andragogy and SDL: Pillars of adult learning theory. New Directions for Adult and Continuing Education, 89, 3-14. https://doi.org/10.1002/ace.3

Merriam, S., Caffarella, R., \& Baumgartner, L. (2007). Learning in adulthood: a comprehensive guide (3rd ed.) San Francisco: John Wiley.

Murnane, R., \& Levy, F. (1996). Teaching the New Basic Skills: Principles for Educating Children to Thrive in a Changing Economy. New York: Free Press.

O'Shea, E. (2003). Self-directed learning in nurse education: A review of the literature. Journal of Advanced Nursing, 43(1), 62-70. https://doi.org/10.1046/j.1365-2648.2003.02673.x

Prasad, E., \& Prasad, R. (2012). Social media in teaching and learning. International Journal of Computer Science and Communication Engineering, 10-13.

Reio, T., \& Leitsch, P. (2003). A preliminary exploration of the relationship between self-directed learning and critical thinking. In H. B. Long, \& Associates (Eds.), Current Developments in E-Learning \& Self-Directed Learning (pp. 185-196). Melrose, FL: International Self-Directed Learning Symposium.

Ruelland, D. (2003). eLearning, a support system for the workplace. In H. B. Long, H. B \& Associates (Eds.). Current developments in e-learning \& self-directed learning (pp. 235-242). Boynton Beach, FL: Motorola University. 
Sanders, K. (2012). An examination of the academic networking site Edmodo on student engagement and responsible learning. (Doctoral dissertation) Retrieved from ProQuest Dissertations and Theses database. (UMI Number 3523217).

Shaikh, R. (2013). Comparison of Readiness for Self-Directed Learning in Students Experiencing Two Different Curricula in One Medical School. Gulf Medical Journal, 2, 27-31.

Stockdale, S. (2003). Development of an instrument to measure self-directedness. Dissertation Abstracts International, A64/06, AAT 3092836.

Stockdale, S., \& Brockett, R. (2011). Development of the PRO-SDLS: A measure of self-direction in learning based on the personal responsibility orientation model. Adult Education Quarterly, 61(2), 161-180. https://doi.org/10.1177/0741713610380447

Tough, A. (1967). Learning without a teacher. Educational Research Series, no. 3. Toronto: Ontario Institute for Studies in Education.

Tough, A. (1971). The adult's learning projects: A fresh approach to theory and practice in adult learning. Toronto: Ontario Institute for Studies in Education.

Turkmen, G. (2012). Using social networking in EFL classroom in higher education. Conference proceedings of "eLearning and Software for Education" (eLSE), 1,350-354. http://www.ceeol. com

Yang, Y. (2015). Self-directed learning to develop autonomy in an online ESP community. Interactive Learning Environments, 1-18.

Yen, C., \& Liu, S. (2009). Learner autonomy as a predictor of course success and final grades in community college online courses. Journal of Educational Computing Research, 41, 347-367. https://doi.org/10.2190/EC.41.3.e 


\section{Appendix}

The Personal Responsibility Orientation to Self-Direction in Learning Scale (PRO-SDLS)

Name:

Date:

ID\#

Please check one answer for each statement. There are no "right answers" to these statements.

\begin{tabular}{|c|c|c|c|c|c|}
\hline ITEM & $\begin{array}{l}\text { Strongly } \\
\text { Disagree }\end{array}$ & Disagree & Sometimes & Agree & $\begin{array}{l}\text { Strongly } \\
\text { Agree }\end{array}$ \\
\hline $\begin{array}{l}\text { 1. I am confident in my ability to consistently } \\
\text { motivate myself. }\end{array}$ & 1 & 2 & 3 & 4 & 5 \\
\hline $\begin{array}{l}\text { 2. I frequently do extra work in a course just because } \\
\text { I am interested. }\end{array}$ & 1 & 2 & 3 & 4 & 5 \\
\hline $\begin{array}{l}\text { 3. I don't see any connection between the work I do } \\
\text { for my courses and my personal goals and interests. }\end{array}$ & 5 & 4 & 3 & 2 & 1 \\
\hline $\begin{array}{l}\text { 4. If I am not doing as well as I would like in a } \\
\text { course, I always independently make the changes } \\
\text { necessary for improvement. }\end{array}$ & 1 & 2 & 3 & 4 & 5 \\
\hline $\begin{array}{l}\text { 5. I always effectively take responsibility for my own } \\
\text { learning. }\end{array}$ & 1 & 2 & 3 & 4 & 5 \\
\hline 6. I often have a problem motivating myself to learn. & 5 & 4 & 3 & 2 & 1 \\
\hline $\begin{array}{l}\text { 7. I am very confident in my ability to } \\
\text { independently prioritize my learning goals. }\end{array}$ & 1 & 2 & 3 & 4 & 5 \\
\hline $\begin{array}{l}\text { 8. I complete most of my college activities because I } \\
\text { WANT to, not because I HAVE to. }\end{array}$ & 1 & 2 & 3 & 4 & 5 \\
\hline $\begin{array}{l}\text { 9. I would rather take the initiative to learn new } \\
\text { things in a course rather than wait for the instructor } \\
\text { to foster new learning. }\end{array}$ & 1 & 2 & 3 & 4 & 5 \\
\hline $\begin{array}{l}\text { 10. I often use materials I've found on my own to } \\
\text { help me in a course. }\end{array}$ & 1 & 2 & 3 & 4 & 5 \\
\hline $\begin{array}{l}\text { 11. For most of my classes, I really don't know why I } \\
\text { complete the work I do. }\end{array}$ & 5 & 4 & 3 & 2 & 1 \\
\hline $\begin{array}{l}\text { 12. I am very convinced I have the ability to take the } \\
\text { personal control of my learning. }\end{array}$ & 1 & 2 & 3 & 4 & 5 \\
\hline $\begin{array}{l}\text { 13. I usually struggle in classes if the professor } \\
\text { allows me to set my own timetable for work } \\
\text { completion. }\end{array}$ & 5 & 4 & 3 & 2 & 1 \\
\hline $\begin{array}{l}\text { 14. Most of the work I do in my courses is personally } \\
\text { enjoyable or seems relative to my reasons for } \\
\text { attending college. }\end{array}$ & 1 & 2 & 3 & 4 & 5 \\
\hline $\begin{array}{l}\text { 15. Even after a course is over, I continue to spend } \\
\text { time learning about the topic. }\end{array}$ & 1 & 2 & 3 & 4 & 5 \\
\hline $\begin{array}{l}\text { 16. The primary reason I complete course } \\
\text { requirements is to obtain the grade that is expected of } \\
\text { me. }\end{array}$ & 5 & 4 & 3 & 2 & 1 \\
\hline $\begin{array}{l}\text { 17. I often collect additional information about } \\
\text { interesting topics even after the course has ended. }\end{array}$ & 1 & 2 & 3 & 4 & 5 \\
\hline $\begin{array}{l}\text { 18. The main reason I do the course activities is to } \\
\text { avoid feeling guilty or getting a bad grade. }\end{array}$ & 5 & 4 & 3 & 2 & 1 \\
\hline $\begin{array}{l}\text { 19. I am very successful at prioritizing my learning } \\
\text { goals. }\end{array}$ & 1 & 2 & 3 & 4 & 5 \\
\hline $\begin{array}{l}\text { 20. Most of the activities I complete for my college } \\
\text { classes are NOT really personally useful or }\end{array}$ & 5 & 4 & 3 & 2 & 1 \\
\hline
\end{tabular}




\begin{tabular}{|c|c|c|c|c|c|}
\hline interesting. & & & & & \\
\hline $\begin{array}{l}\text { 21. I am really uncertain about my capacity to take } \\
\text { primary responsibility for my learning. }\end{array}$ & 5 & 4 & 3 & 2 & 1 \\
\hline $\begin{array}{l}\text { 22. I am unsure about my ability to independently } \\
\text { find needed outside materials for my courses. }\end{array}$ & 5 & 4 & 3 & 2 & 1 \\
\hline 23. I always effectively organize my study time. & 1 & 2 & 3 & 4 & 5 \\
\hline $\begin{array}{l}\text { 24. I don't have much confidence in my ability to } \\
\text { independently carry out my study plans. }\end{array}$ & 5 & 4 & 3 & 2 & 1 \\
\hline $\begin{array}{l}\text { 25. I always rely on the instructor to tell me what I } \\
\text { need to do in the course to succeed. }\end{array}$ & 5 & 4 & 3 & 2 & 1 \\
\hline
\end{tabular}

TOTAL SCORE:

Teaching Learning Transaction Component $=$ Total of Initiative and Control Factors from below Factors:

Initiative $=$ Total of scores from numbers $2,9,10,15,17,25$

Control $=$ Total of scores from numbers 4,5,6,13,19,23

Learner Characteristics Component $=$ Total of Self-efficacy and Motivation Factors from below

Factors:

Self-Efficacy $=$ Total of scores from numbers $1,7,12,21,22,24$

Motivation $=$ Total of scores from numbers 3,8,11,14,16,18,20

\section{Copyrights}

Copyright for this article is retained by the author(s), with first publication rights granted to the journal.

This is an open-access article distributed under the terms and conditions of the Creative Commons Attribution license (http://creativecommons.org/licenses/by/4.0/). 